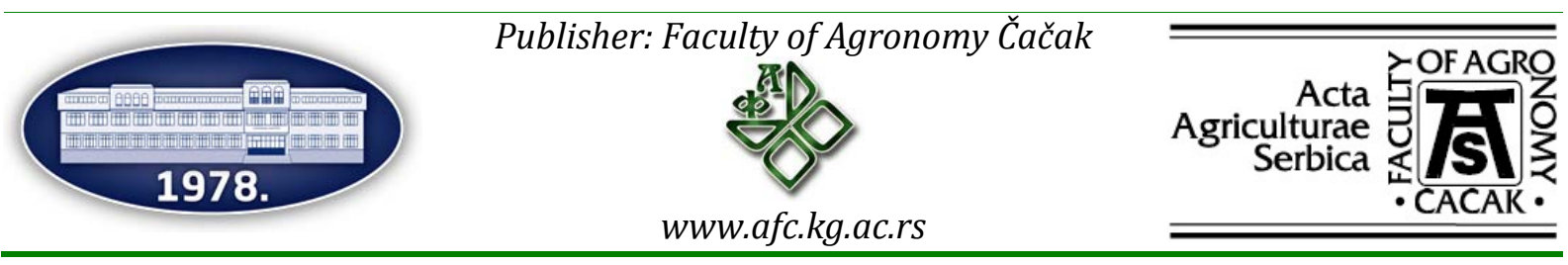

\title{
Survey of Apple Collar and Rootstock Blight in Serbia
}

\author{
Renata Iličić1, Tatjana Popović \\ ${ }^{1}$ Faculty of Agriculture, University of Novi Sad, Department of Plant and Environmental Protection, Trg Dositeja \\ Obradovića 8, 21000 Novi Sad, Serbia \\ ${ }_{2}^{2}$ Institute for Plant Protection and Environment, Teodora Drajzera 9, 11040 Belgrade, Serbia
}

*Corresponding author: renatailicic@gmail.com

Received 10 June 2020; Accepted 1 June 2021

\begin{abstract}
A B S T R A C T
Apple production in Serbia is characterized by the introduction of new technologies and the establishment of intensive plantations based on modern systems. In intensive apple production systems, sudden and rapid decay of young apple trees exhibiting collar and rootstock blight symptoms in the first few years after planting is becoming a prevalent issue. However, knip or nursery trees with lateral branches (feathers) on rootstock M.9 i.e. one- to five-year old are most seriously affected. Based on a longitudinal survey of young apple plantations in Serbia and the results of pathogen detection and identification using conventional and molecular methods, the plant pathogenic bacterium Erwinia amylovora was found as the causative agent. By increasing the incidence of collar and rootstock blight in young apple trees, E. amylovora is gaining importance as the most destructive disease in apple production. In order to control E. amylovora effectively and apply appropriate control measures, it is necessary to survey the development of lesser-known symptoms caused by this pathogen, which are becoming prevalent in Serbian agroecological conditions.
\end{abstract}

Keywords: apple, decay, collar, rootstock, Erwinia amylovora.

\section{И 3 В $О$ Д}

Производњу јабуке у Србији карактерише увођење нових технологија и подизање интензивних засада са најсавременијим системима. У првих неколико година по садњи, у системима интензивне производње јабуке, све чешће се јавља проблем изненадног и брзог сушења целих, младих стабала са симптомима некрозе кореновог врата и подлоге. Углавном су то книп или саднице са превременим гранама на слабобујној подлози - М.9, старости до пет година. Током вишегодишњег праћења ове појаве у младим засадима и лабораторијских резултата идентификације проузроковача применом класичних и савремених метода, утврђено је присуство бактерије Erwinia amylovora. С обзиром на све чешћу појаву некрозе кореновог врата и подлоге у младим засадима јабуке, E. amylovora добија све већи значај и постаје најдеструктивније обољење у производњи јабуке. У циљу ефикасног сузбијања E. amylovora и примене адекватних мера заштите, неопходно је пратити заступљеност и развој мање познатих симптома овог патогена, који се у нашим условима последњих година све чешће јављају.

Кључне речи: јабука, сушење, коренов врат, подлога, Erwinia amylovora.

\section{Introduction}

The plant pathogenic bacterium Erwinia amylovora, the causative agent of fire blight on pome fruits, is widespread in Europe, Asia, North Africa, the Eastern Mediterranean, North and Central America and New Zealand (Bonn and van der Zwet, 2000; Van der Zwet, 2002; CABI/EPPO, 2007; OEPP/EPPO, 2013). This bacterium has been described to be pathogenic for 200 plant species, mainly affecting those within the Rosaceae family, but also the genera Chaenomeles, Cotoneaster, Crataegus, Cydonia, Eriobotria, Malus, Mespilus, Pyrus, Photinia, Pyracantha, Sorbus, and Stranvaesia. However, the most extensive losses have been recorded on pear, apple and quince cultivars in many countries including Serbia (Popović et al., 2020). E. amylovora has been described on raspberries (Starr et al., 1951; Atanasova et al., 2005), Japanese and
European plums (Vanneste et al., 2002), hokeberry (Aronia melanocarpa) (Atanasova et al., 2005), Spirea prunifolia, Rosa canina and R. rugosa (Bastas et al., 2013; Bastas and Sahin, 2014). In neighboring Hungary, this bacterium has also been described as a pathogen of stone fruit species such as European plum (Prunus domestica) (Végh et al., 2012), cherry plum (P. cerasifera), and apricot ( $P$. armeniaca) (Végh and Pavlovics, 2013, 2016). Considering that the presence of this pathogen in stone fruit species has recently been identified in Hungary, E. amylovora has the potential for future spread to new hosts in Serbia as well.

E. amylovora is on the EPPO (The European and Mediterranean Plant Protection Organization) A2 list of quarantine pathogens in the European Union, confirmed in 51 countries (OEPP/EPPO 2013). In Serbia, E. amylovora is on the list IA part II of harmful organisms (Službeni Glasnik RS, 2015). 
Fire blight is difficult to control, considering that the bacterium is able to rapidly spread in the host plant. Therefore, effective control methods are still lacking (Vrancken et al., 2013). E. amylovora has become a serious issue in high density apple plantations comprising new susceptible cultivars and dwarfing rootstocks (Ontario, 2016).

The typical symptoms caused by E. amylovora include blossom, fruit, shoot, perennial branch, limb and trunk blight (Popović et al., 2020). The most specific and common symptom in Serbian conditions is shoot blight and bending in the form of a "shepherd's crook" during summer months (Figure 1). A less common and lesser known symptom caused by this bacterium is collar and rootstock blight (Van der Zwet and Beer, 1991; Vanneste, 2000; Johnson, 2000; Solymar et al., 2002; Ontario, 2009). According to Van der Zwet and Beer (1991), collar and root infections lead to rapid death of infected apple trees, causing major losses in commercial plantations. In Serbia, the occurrence of such symptoms in young apple trees was previously reported by Gavrilović et al. (2008) and Iličić et al. (2016).

During recent years, apple collar and rootstock blight symptoms capable of causing rapid decay of the entire young apple tree in intensive orchards on rootstock M.9 have frequently been observed in Serbia (Figure 2). Therefore, the aim of the present study was to determine and identify the causative agent of rapid apple tree decay, using conventional and molecular methods. The results yielded by this study will enable proper pathogen management in the implementation of appropriate control measures.

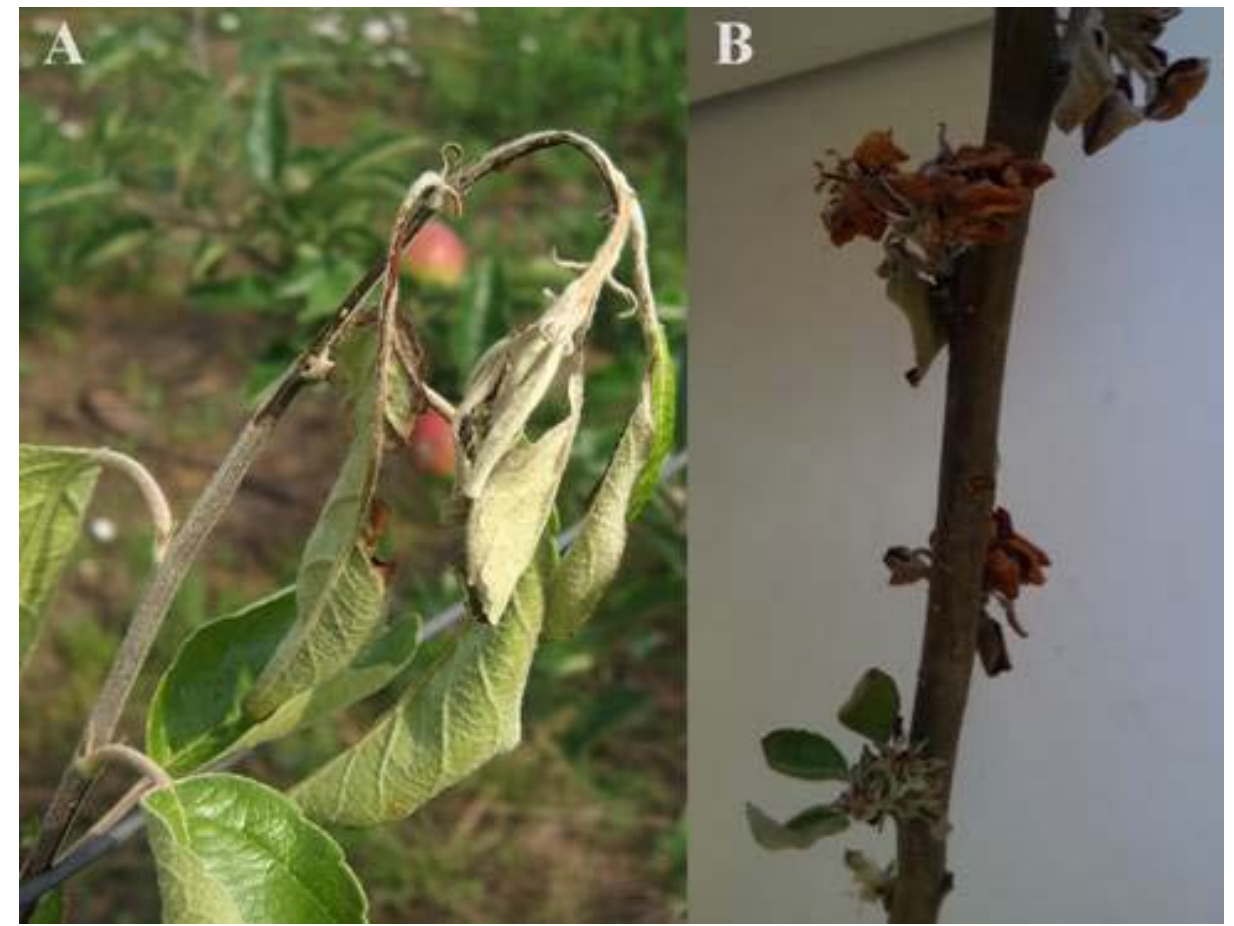

Figure 1. Symptoms of Erwinia amylovora infection on apple. A - Shoot blight ("shepherd's crook"); B - Blossom blight (photo: T. Popović)

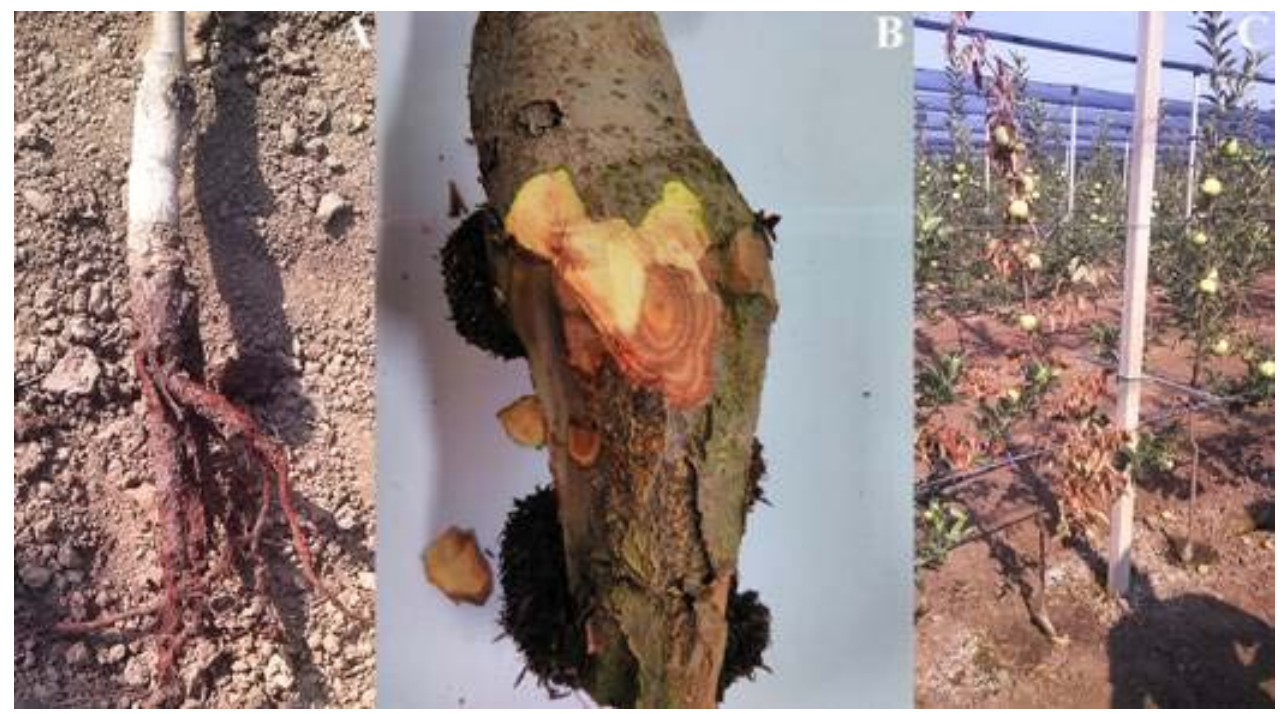

Figure 2. Erwinia amylovora collar and rootstock blight. A - Complete decay of the rootstock and root; B - Necrosis of internal tissues; C - Leaves warping and blackening as a consequence of rootstock blight (photo: R. Iličić) 


\section{Materials and methods}

\subsection{Sample collection and pathogen isolation}

With the aim of determining the causative agent of rapid young apple tree decay, samples exhibiting collar and rootstock blight symptoms were collected from a number of leading, attractive and club apple cultivars, knip or trees with lateral branches (feathers) grafted on the rootstock M.9 (Table 1). A total of seventeen localities where the symptoms appeared during the eight-year survey period (2013-2020) were included in the analysis (Table 1)

The collected samples were washed under tap water and dried on filter paper, before being disinfected with $70 \%$ ethanol. After removing the bark, small segments were taken between the healthy and the diseased part of the tissue, which was reddishbrown in color (Figure 2.B). Isolations were performed simultaneously for plant pathogenic bacteria on Nutrient Agar supplemented with 5\% of sucrose (NSA) and for plant pathogenic fungi on Potato Dextrose Agar (PDA). For the isolation of bacteria, the fragments were first macerated in sterile distilled water (SDW) and were left for 60 minutes at room temperature before plating onto the NSA medium. The plates were incubated at $27^{\circ} \mathrm{C}$ for 2 days (Lelliott and Stead, 1987). For the isolation of fungi, small fragments (1-2 $\mathrm{mm}$ in length) were placed on the PDA and were kept at $25^{\circ} \mathrm{C}$ for 14 days (Karwa et al., 2012). From plates where dominant bacterial colonies formed whitish, mucoid colonies, 2-4 isolates from each locality (Table 1) were purified by transferring to new plates. Isolates were maintained as stock cultures, which were stored at $20^{\circ} \mathrm{C}$ in Luria Bertani (LB) broth containing $20 \%(\mathrm{v} / \mathrm{v})$ glycerol.

For all tests, isolates were grown on NSA at $27^{\circ} \mathrm{C}$ for $48 \mathrm{~h}$. The reference strain of E. amylovora NCPPB 683 (The National Collection of Plant Pathogenic Bacteria, FERA, York, UK) was used in all tests and reactions for comparison.

\subsection{Pathogenicity}

The pathogenicity of bacterial isolates was evaluated on immature fruits of pear cv. Kaluđerka, using the puncturing inoculation method. Fruits were first washed and dried on sterile filter paper, before being disinfected with $70 \%$ ethanol. Isolates were suspended in SDW to the final concentration of $10^{8} \mathrm{CFU}$ $\mathrm{mL}^{-1}$. SDW and the reference strain NCPPB 683 were used as negative and positive control treatments, respectively. Inoculated fruits were kept in plastic boxes with high relative humidity at room temperature for several days. The development of fruit necrosis and bacterial exudate was checked on a daily basis.

\subsection{Biochemical tests}

Bacterial isolates were tested for Gram reaction, levan production on NSA medium, presence of catalase and oxidase, production of fluorescent pigment on King's B medium, oxidative-fermentative (O/F) metabolism of glucose, nitrate reduction, gelatin, starch, and esculin liquefaction (Lelliott and Stead, 1987; Schaad et al., 2001).

\subsection{Molecular identification}

Total DNA was extracted from $48 \mathrm{~h}$ old pure culture grown on NSA medium according to the protocol described by Ross et al. (2000). Polymerase chain reaction (PCR) was carried out with different specific primer pairs derived from plasmid pEA29, one for conventional PCR using primer pair A/B (Bereswill et al., 1992) and others for nested PCR using two sets of primers - PEANT1/PEANT2 (Llop et al., 2000) and AJ75/AJ76 (McManus and Jones, 1995).

For the A/B primer pair, PCR amplification was performed in $25 \mu \mathrm{L}$ reaction volume, consisting of 12.5 $\mu \mathrm{L}$ of DreamTaq Green PCR Master Mix, $1 \mu \mathrm{L}$ of template DNA, $1 \mu \mathrm{L}$ of each of the primers $(10 \mu \mathrm{M})$ and $9.5 \mu \mathrm{L}$ of ultrapure DNase/RNase-free water, following the protocol involving initial denaturation at $94^{\circ} \mathrm{C}$ for 2 min, followed by 37 cycles of denaturation at $94^{\circ} \mathrm{C}$ for 1 min, annealing at $52^{\circ} \mathrm{C}$ for $2 \mathrm{~min}$, elongation at $72^{\circ} \mathrm{C}$ for $2 \mathrm{~min}$, and final elongation at $72^{\circ} \mathrm{C}$ for $10 \mathrm{~min}$.

Nested PCR was carried out in $25 \mu \mathrm{L}$ reaction volume, comprising $14 \mu \mathrm{L}$ of DreamTaq Green PCR Master Mix (Thermo Fisher Scientific), $1 \mu \mathrm{L}$ of template DNA, $1 \mu \mathrm{L}$ each of primers PEANT1/PEANT2, $0.32 \mu \mathrm{L}$ each of primers AJ75/AJ76 and 7.36 $\mu \mathrm{L}$ of ultrapure DNase/RNase-free water. The reaction conditions were as follows: initial denaturation step of $94^{\circ} \mathrm{C}$ for $4 \mathrm{~min}$, followed by 25 cycles of $94^{\circ} \mathrm{C}$ for $30 \mathrm{~s}$ and $72^{\circ} \mathrm{C}$ for 1 $\mathrm{min}$. This first round of PCR was followed by the second reaction in the same thermocycler, in which the initial denaturation step of $94^{\circ} \mathrm{C}$ for 4 min was followed by 40 cycles of $94^{\circ} \mathrm{C}$ for $30 \mathrm{~s}, 56^{\circ} \mathrm{C}$ for $30 \mathrm{~s}$, and $72^{\circ} \mathrm{C}$ for $45 \mathrm{~s}$.

The PCR products were visualized after electrophoresis on $1.5 \%$ agarose gel, stained with ethidium bromide and photographed under a UV transilluminator. The length of expected amplicons was determined by comparison with the DNA molecular weight markers GeneRuler 100 bp DNA Ladder, ready to use (Thermo Scientific, Lithuania).

\section{Results and discussion}

Increasing incidence of a sudden and rapid decay of young trees has been noticed in almost all apple production regions in Serbia. These symptoms were present throughout the growing season, mainly on young (one- to five-year old) trees. The first symptoms appeared in the leaves of infected trees, which warped, darkened, and not fall out. The overall appearance was akin to that of a dehydrated tree during drought (Figure 2.C). In the collar root area, the tissue was reddish-brown in color, while the bark was peeling and cracking in the rootstock part below the graft union (Figure 2.B). In the worst cases, necrosis spread from the collar into roots, completely girdling the rootstock, due to which tree rot and decay occurred (Figure 2.A). Upon removal of the diseased bark, reddish-brown stripes were noted in the internal tissues (Figure 2.B), and such trees completely dried in the subsequent weeks. Common symptoms of E. amylovora infection, such as blossom, shoot, and fruit blight were also apparent (Figure 1.A and 1.B), but were sporadic and their extent depended on weather conditions.

After the pathogen isolation, many bacterial colonies were formed on the NSA medium after $48 \mathrm{~h}$, most of which were round, cream-whitish, large, 
convex, mucoid and levan positive. For the identification, 69 bacterial isolates were selected, comprising 2-4 representatives from each observed locality (Table 1).

Table 1.

Survey of collar and rootstock blight symptoms

\begin{tabular}{|c|c|c|c|}
\hline District & Locality & Year of isolation & Isolate code \\
\hline \multirow{10}{*}{ South Bačka } & \multirow{2}{*}{ Selenča } & September 2013 & FB13-(1-3) \\
\hline & & May 2014 & FB14-(1-2) \\
\hline & Čelarevo & October 2016 & FB16-(1-4) \\
\hline & \multirow{2}{*}{ Sirig } & April 2016 & FB16-(5-6) \\
\hline & & June 2017 & FB17-(1-2) \\
\hline & \multirow{3}{*}{ Rimski Šančevi } & September 2017 & FB17-(3-5) \\
\hline & & October 2018 & FB18-(1-4) \\
\hline & & September 2019 & FB19-(1-2) \\
\hline & Kulpin & July 2018 & FB18-(5-6) \\
\hline & Tovariševo & June 2016 & FB16-(7-9) \\
\hline \multirow{3}{*}{ Srem } & Krčedin & May 2015 & FB15-(1-2) \\
\hline & Inđija & April 2018 & FB18-(7-8) \\
\hline & Jazak & March 2019 & FB19-(3-4) \\
\hline \multirow[t]{5}{*}{ North Bačka } & \multirow[t]{4}{*}{ Subotica } & June 2015 & FB15-(3-4) \\
\hline & & June 2016 & FB16-(10-12) \\
\hline & & May 2017 & FB17-(6-7) \\
\hline & & June 2018 & FB18-(9-10) \\
\hline & Bačka Topola & May 2016 & FB16-(13-15) \\
\hline Banat & Pančevo & June 2015 & FB15-(5-6) \\
\hline Jablanica & Leskovac & April 2015 & FB15-(7-9) \\
\hline \multirow[t]{2}{*}{ Belgrade } & \multirow[t]{2}{*}{ Mladenovac } & May 2015 & FB15-(10-11) \\
\hline & & September 2017 & FB17-(8-9) \\
\hline \multirow[t]{2}{*}{ Šumadija } & \multirow[t]{2}{*}{ Aranđelovac } & May 2018 & FB18-(11-14) \\
\hline & & June 2019 & FB19-(5-6) \\
\hline \multirow[t]{3}{*}{ Danube } & \multirow[t]{3}{*}{ Smederevo } & June 2015 & FB15-(12-13) \\
\hline & & April 2016 & FB16-(16-17) \\
\hline & & May 2017 & FB17-(10-12) \\
\hline Toplica & Žitorađa & April 2020 & FB20-(1-2) \\
\hline
\end{tabular}

The pathogenicity of all 69 selected bacterial isolates was confirmed on immature pear fruits, which exhibited necrotic spots with drops of whitish exudates 48-72 $\mathrm{h}$ after the inoculation, similar to those caused by the reference strain E. amylovora NCPPB 683. Fruits treated with SDW were symptomless.

All isolates were Gram negative, produced levan and catalase, but not oxidase or fluorescent pigment on King's B medium. O/F test indicated that the isolates utilized glucose aerobically and anaerobically (facultative anaerobic), hydrolyzed gelatin, but did not hydrolyze starch or aesculin, and did not reduce nitrates. The same reactions were obtained when the reference strain E. amylovora NCPPB 683 was used.

PCR amplification with the specific primer pair $\mathrm{A} / \mathrm{B}$ showed positive reaction in all isolates and the reference strain NCPPB 683 by producing a speciesspecific band $900 \mathrm{bp}$ in size, identifying them as $E$. amylovora. Using nested-PCR, fragments in size of 391-450 bp were amplified, which also confirmed that the isolates belong to the bacterium E. amylovora.

The results obtained in this work in the identification of E. amylovora isolates using classical and molecular methods concur with those reported by other authors (Gavrilović, 2010; Gavrilović et al., 2008; Radunović, 2018; Popović et al., 2020). Based on the findings pertaining to the morphological and biochemical characteristics, pathogenicity, and identification achieved using molecular methods, it was
There was no development of pathogenic fungi as potential causal agents of apple tree decay on the PDA medium. concluded that the collar and rootstock blight symptoms causing young apple tree decay in Serbia were caused by the bacterium E. amylovora.

Fire blight of pome fruit species caused by $E$. amylovora is among the most serious diseases. In recent years, modern apple plantations have been established from planting material mostly imported from Italy, the Netherlands, and Greece. Apple, as the most important pome fruit species in Serbia, is grown on 23. $737 \mathrm{ha}$, and the largest apple orchards are in the municipalities of Subotica, Smederevo, Grocka, Čačak, and Arilje, while smaller ones are located in the Srem region, parts of Šumadija, Southern Banat, and Southern Bačka (Keserović et al., 2016).

The presence of E. amylovora on the apple collar and rootstock in Serbia was previously confirmed by Gavrilović et al. (2008) and Iličić et al. (2016). Appearance of E. amylovora on the collar is caused by the spreading of bacteria through vegetative rootstocks. Gavrilović et al. (2008) stated that root collar infections are not the most common phase of the fire blight disease, but they are most destructive because complete tree decay occurs in the first years following infection. This assertion is supported by our results obtained after eight-year-long disease survey. Increasing humidity in the root collar zone, due to watering and fertilizing the fruit trees via the drip irrigation system, provides ideal conditions for the spreading of bacteria, exacerbating apple tree decay. 
The most important factors for the disease spread are latent infections of the rootstock, infected blossoms or young shoots, various types of mechanical damage caused during operations in the nursery/plantation, improper apple tree storage, dense planting, and inadequate application of herbicides in the collar zone (Iličić et al., 2016). According to Van der Zwet and Beer (1991), collar invasion by E. amylovora occurs through infected suckers or water sprouts, washed bacteria from infected twigs and fruit down the trunk, or internal translocation from the infected above-ground cultivar scions to the rootstock. The collar root blight symptoms most often occur when infected rootstocks are used during grafting, and most rootstocks, including M.9 and M.26, are highly susceptible to $E$. amylovora (Zwet and Beer, 1991; Johnson, 2000; Gavrilović et al., 2008). These symptoms are very similar to those caused by the plant pathogenic fungi Phytophthora spp., which makes the correct diagnosis difficult, often resulting in the application of inappropriate control measures.

In order to take this increasingly frequent occurrence of E. amylovora on the collar and rootstock under control, more attention should be paid to the health status of trees, planting material and rootstocks used for grafting. Sterilization of pruning tools during the grafting process in nurseries, using $70 \%$ ethanol or $10 \%$ hypochlorite solution, is also recommended. In established plantations, use of herbicides that are commonly applied for root sucker growth reduction should be avoided, while also preventing all types of rootstock damage and eliminating any potential entry points for fire blight. In apple orchards and plantations where the appearance of E. amylovora on the collar root and rootstock has been confirmed, the elimination of the infection source is the only effective control method, as uprooting and burning the infected trees would reduce the infectious potential.

\section{Conclusions}

During the eight-year survey (2013-2020) of collar and rootstock blight symptoms on young apple trees in nine growing districts in Serbia, the bacterium $E$. amylovora was detected and confirmed to be the causal agent of the disease. This lesser known symptom of the disease occurs more frequently and leads to the rapid decay of young apple trees; therefore, the use of pathogen-free planting material is the main strategy in disease control management.

\section{Acknowledgment}

The work is the result of a project of the Ministry of Education, Science and Technological Development of the Republic of Serbia, Contracts No. 451-039/2021-14/200117 and 451-03-9/2021-14/200010.

\section{Declaration of competing interest}

The authors declare that they have no conflicts/competing interests.

\section{References}

Atanasova, I., Kabadjova, P., Bogatzevska, N., Moncheva ,P. (2005). New Host Plants of Erwinia amylovora in Bulgaria. Zeitschrift für Naturforschung C, 60, 893-8.

Bastas, K.K., Sahin, F., Atasagun, R. (2013). First report of fire blight caused by Erwinia amylovora on rosehip (Rosa canina) in Turkey. Plant Disease, 97, 1652.

Bastas, K.K., Sahin, F. (2014). First report of fire blight caused by Erwinia amylovora on meadowsweet (Spirea prunifolia) in Turkey. Plant Disease, 98, 153.

Bereswill, S., Pahl, A., Bellemann, P., Zeller, W., Geider, K. (1992). Sensitive and species-specific detection of Erwinia amylovora by polymerase chain reaction analysis. Applied and Environmental Microbiology, 58(11), 3522-3526.

Bonn, W.G., Van der Zwet, T. (2000). Distribution and economic importance of fire blight. In: J.L.Vanneste (ed.), Fire blight: The Disease and its Causative Agent, Erwinia amylovora, CABI Publishing. Wallingford. UK, pp. 37-53.

CABI/EPPO (2007). Erwinia amylovora. Distribution Maps of Plant Diseases, No. 2. Wallingford (GB).

Gavrilović, V. (2010). Ornamental and spontaneous plantshosts of Erwinia amylovora in Serbia. Plant Protection, 61(3), 169-180.

Gavrilović, V., Milijašević-Marčić, S., Todorović, B., Živković, S., Trkulja, N. (2008). Erwinia amylovora - the Causal Agent of Root Collar Necrosis of Apple Trees. Pesticides and Phytomedicine, 23, 17-23.

Iličić, R., Balaž, J., Ognjanov, V., Vlajić, S. (2016). Frequency of findings Erwinia amylovora - the causal agent of root collar necrosis of apple trees. 9th International scientific/professional conference Agriculture in nature and environment protection, Vukovar, Republic of Croatia, 6-8 June, 133-134.

Johnson, K.B. (2000). Fire blight of apple and pear. The Plant Health Instructor.

Karwa, A.S., Rai, M.K. Singh, H.B. (2012). Handbook of Techniques in Microbiology: A Laboratory Guide to Microbes. Scientific Publishers India.

Keserović, Z., Magazin, N., Milić, B., Dorić, M. (2016). Voćarstvo i Vinogradarstvo - deo Voćarstvo. Poljoprivredni fakultet, Novi Sad.

Lelliott, R.A., Stead, D.E. (1987). Methods for the diagnosis of bacterial diseases of plants. Oxford, London, Edinburgh: British Society for Plant Pathology, Blackwell Scientific Publications.

Llop, P., Bonaterra, A., Peñalver, J., López, M.M. (2000). Development of a highly sensitive nested-PCR procedure using single closed tube for detection of Erwinia amylovora in asymptomatic plant material. Applied and Environmental Microbiology, 66, 2071-2078.

McManus, P.S., Jones, A.L. (1995). Detection of Erwinia amylovora by nested-PCR and PCR-dot-blot and reverse blot hybridisations. Phytopathology, 85, 618-623.

OEPP/EPPO (2013). Diagnosis of Erwinia amylovora. Protocol for the diagnosis of quarantine organism. SMT Project SMT-4-CT98-2252. OEPP/EPPO Bulletin, 43: 21-45. Ontario (2009): Fire Blight - Collar \& Rootstock. Ministry of Agriculture, Food and Rural Affairs, Guelph, ON. Available http://www.omafra.gov.on.ca/IPM/english/apples/disea ses-and-disorders/fire-blight-collar-rootstock.html.

Ontario (2016). Publication 310 - Integrated pest management for apples - Fire Blight. Ministry of Agriculture, Food and Rural Affairs, Guelph, ON. Available at:

http://www.omafra.gov.on.ca/english/crops/facts/firebl ight.htm.

Popović, T., Jelušić, A., Živković, Lj., Živković, N., Iličić, R., Stanisavljević, R., Stanković, S. (2020). Identification, genetic characterization and virulence of Serbian Erwinia amylovora isolates. European Journal of Plant Pathology, $157,857-872$.

Radunović, D. (2018). Distribution, plant hosts and characterization of Erwinia amylovora population in 
Montenegro. PhD thesis. University of Novi Sad, Faculty of Agriculture.

Ross, L.I., Alami, Y., Harvey, R.P., Achouak, W., Ryder, M.H. (2000). Genetic Diversity and Biological Control Activity of Novel Species of Closely Related Pseudomonads Isolated from Wheat Field Soil in South Australia. Applied and Environmental Microbiology, 66, 1609-1616.

Schaad, N.W., Jones, J.B., Chun, W. (2001). Laboratory Guide for Identification of Plant Pathogenic Bacteria, Third Edition, APS Press.

Službeni Glasnik RS (2015). Pravilnik o izmenama pravilnika o listama štetnih organizama i listama bilja, biljnih proizvoda i propisanih objekata, br. 57/15. Ministarstvo Poljoprivrede, Šumarstva i Vodoprivrede, Uprava za Zaštitu bilja, Beograd, Srbija.

Solymar, B., Walker, G., Bonn, G., Carter, N. (2002). Fire blight of apple and pear in Ontario. Ministry of Agriculture, Food and Rural Affairs, Ontario, AGDEX 634/210.

Starr, M.P., Cardona, C., Folsom, D. (1951). Bacterial fire blight of raspberry. Phytopathology, 41, 951-959.

Van der Zwet, T. (2002). Present worldwide distribution of fire blight. Acta Horticulturae, 590, 33-34.

Van der Zwet T., Beer S.V. (1991). Fire Blight - Its Nature, Prevention and Control. A Practical Guide to Integrated
Disease Management, U.S. Department of Agriculture. Agricultural Bulletin, 631, pp. 83.

Vanneste, J.L. (2000). Fire Blight - The Disease and its Causative Agent, Erwinia amylovora. CABI Publishing.

Vanneste, J.L., Vermeulen, M., Lex, S., Berger, F. (2002). Isolation of Erwinia amylovora from blighted plums (Prunus domestica) and potato roses (Rosa rugosa). Acta Horticulturae, 590, 89-94.

Végh, A., Némethy, Zs., Hajagos, L., Palkovics, L. (2012). First Report of Erwinia amylovora Causing Fire Blight on Plum (Prunus domestica) in Hungary. Plant Diseases, 96(5), 759.

Végh, A., Palkovics, L. (2013). First Occurrence of Fire Blight on Apricot (Prunus armeniaca) in Hungary. Notulae Botanicae Horti Agrobotanici Cluj-Napoca, 41(2), 440443.

Végh, A., Palkovics, L. (2016). First Occurrence of Fire Blight (Erwinia amylovora) on Prunus Species in Hungary. Acta Hotriculturae, 1149, 31-36.

Vrancken, K., Holtappels, M., Schoofs, H., Deckers, T., Valcke, R. (2013). Pathogenicity and infection strategies of the fire blight pathogen Erwinia amylovora in Rosaceae: State of the art. Microbiology, 159, 823-832. 